\title{
A FELÜLETVASALÁS ALAKHELYESSÉGRE ÉS FELÜLETI MIKRO- KEMÉNYSÉGRE GYAKOROLT HATÁSÁNAK VIZSGÁLATA
}

\author{
Ferencsik Viktória \\ egyetemi tanársegéd, Miskolci Egyetem, Gyártástudományi Intézet \\ 3515 Miskolc, Miskolc-Egyetemváros, e-mail: ferencsik.viktoria@uni-miskolc.hu
}

\begin{abstract}
Absztrakt
Jelen tanulmányban az élettartamnövelö felületszilárditó eljárások közé tartozó felületvasalás technológiájának vizsgálatával, bemutatásával, valamint ennek a megmunkálási módnak a hengerességre és felületi mikro-keménységre gyakorolt hatásának elemzésével foglalkozom 42CrMo4 jelölésü ötvözet esetén. Az egyes jellemzök méréséhez egy köralak- és helyzethiba mérö-, valamint egy Vickers keménységet meghatározó berendezést használtam fel annak bizonyitására, hogy a felületvasalás elönyösen alkalmazható ezen az anyagminöségen.
\end{abstract}

Kulcsszavak: élettartam, hidegalakitás, alakhelyesség, felkeményedés

\begin{abstract}
In this study the technology of surface burnishing is investigated and presented, which is one of the lifetime increasing surface strengthening methods. I examine the influence of it on shape correctness and surface micro-hardness on $42 \mathrm{CrMo} 4$ marked alloy. To measure each feature, I used a circular and position error measuring equipment and a Vickers hardness tester device to prove that surface burnishing advantageously applicable to this material.
\end{abstract}

Keywords: lifetime, cold working, shape correctness, hardening

\section{Bevezetés}

A gépek müködésekor a legtöbb igénybevétel elsősorban a gépelemek felületét, illetve bizonyos vastagságú felületi rétegét éri, tehát a megmunkált felület mikro-geometriája nagy hatással van a gépelem kopásállóságára, fárasztó igénybevételek esetén pedig feszültséggyüjtő hatása számottevő [1]. A gépelem felületének minősége pedig esetenként hatékonyabban javítható a tartósságnövelő mechanikai megmunkálásokkal, mint forgácsolással.

A hideg képlékenyalakító eljárások, úgy, mint ütőtestes felületszilárdítás, hengerlés és felületvasalás mindig is jelentős szerepet töltöttek be az iparban. Ezzel a forgácsleválasztás nélküli eljárással kapcsolatban az első szabadalom már az 1910-es években megjelent [2], az utóbbi több, mint egy évszázadban pedig nagymértékü fejlödésen ment keresztül, igazodva az egyre növekvőbb ipari, felhasználói igényekhez.

A csúszó relatív elmozdulást alkalmazó vasalásnak számos előnye van: hatékonyan csökkenti a felületi érdességet, a diszlokációk átrendezése révén növeli a felületközeli réteg mikro-keménységét, korrózióval szembeni ellenállóképességét, továbbá javítható a hengeres felületek alakhelyessége és nem igényel nagy mennyiségü hűtő-kenő folyadékalkalmazást, tehát gazdaságos és kis környezetterhelésü [3].

Az alkalmazott szerszám anyaga lehet edzett acél, keményfém, kerámia, illetve természetes vagy mesterséges gyémánt. 
A gyémántvasalás alkalmas külső és belső hengeres felületek megmunkálására is, a továbbiakban külső hengeres felület gyémántvasalásával, illetve az általa okozott alakhelyességi változás és felkeményedés vizsgálatával foglalkozom részletesebben.

\section{Külső hengeres felületek vasalása}

Forgásszimmetrikus testek vasalásának megvalósítása során egy adott paraméterekkel rendelkező szerszám egyenes vonalú mozgást végezve végighalad a vasalandó, forgó mozgást végző munkadarab felületén. A hidegalakítás megvalósulásához szükséges nyomás a szerszám müködő és a munkadarab alakítandó felülete közötti átfedés hatására jön létre [1], [4], ahogy azt az 1. ábra szemlélteti.

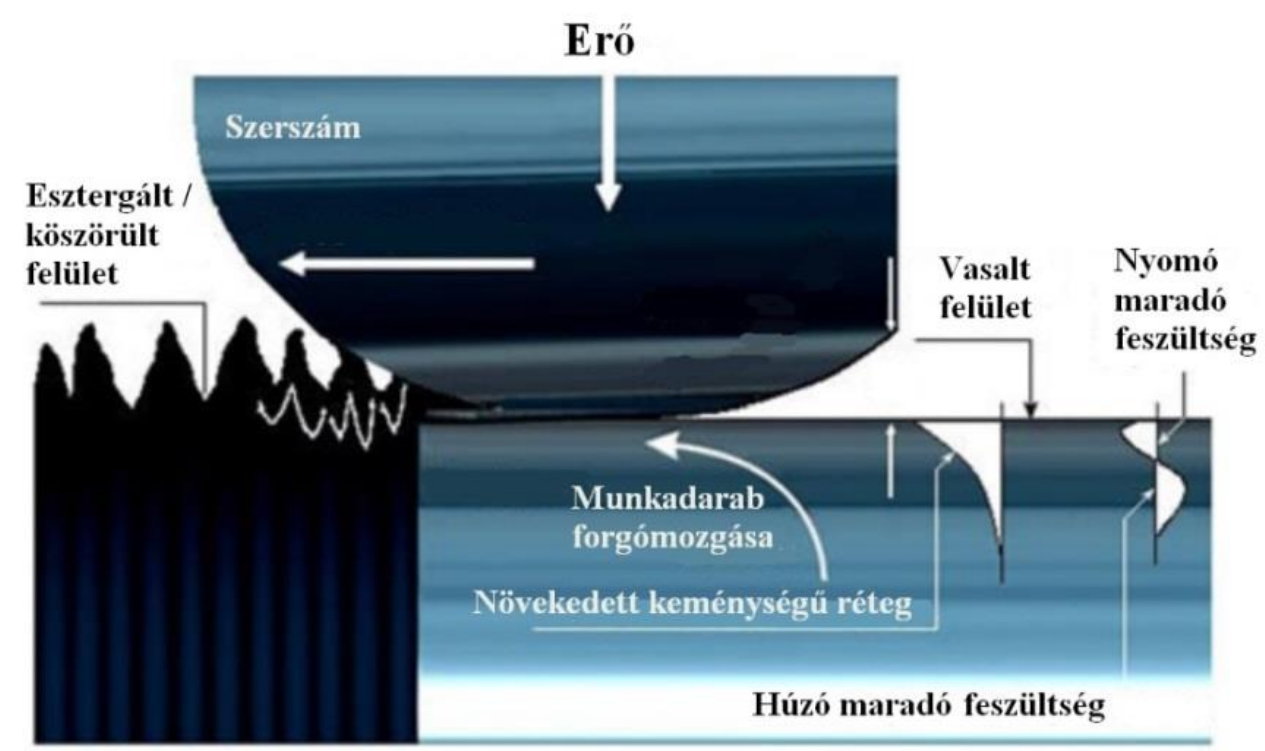

1. ábra $A$ vasalási müvelet kinematikája. [5]

Tehát felületvasaláskor a felület érdességének csökkenését és a felület alakhelyességének javulását a megmunkálandó anyagnál jóval keményebb anyagú szerszám és a vasalandó felület csúszási súrlódásakor végbemenő kölcsönhatása jellemzi [5].

Az eljárás természetesen nem csak külső hengeres felület megmunkálására alkalmas, választásunk azért esett erre, mivel fő alkalmazási területét autóipari, légiipari alkatrészek, fötengelyek, belső és külső csapágy futógyürük, stb. megmunkálása alkotják.

\section{Kísérleti körülmények}

\subsection{A vizsgálat tárgya}

A vasalandó munkadarab anyagminősége és keménysége széles tartományban változhat, Inconel 718 ötvözettől kezdve [6], bronzon át [4], akár a poliuretánig [7]. Jelen kísérlethez hengerelt (Ø 70 x 295 $\mathrm{mm}$ ) nagy szilárdságú ( 1000 MPa) nemesíthető acélt (42CrMo4) választottam, melyek szívósak és ellenállnak a statikus és dinamikus igénybevételeknek. Fö felhasználási területüket képzik a tengely- 
jellegủ alkatrészek, hajtómüvek a gépiparban, jármügyártásban, továbbá szerszámgépelemek, csigakerekek, stb. anyagául is szolgálnak.

A darabot a vasalási folyamatot megelőzően palástköszörüléssel munkálták meg, mivel egy hagyományos befejező megmunkálás eredményeivel kívántuk összevetni a felületvasalás okozta változásokat.

\subsection{A beállított vasalási paraméterek}

Több kutató [1-7] kísérletileg tanulmányozta a vasalási folyamat során alkalmazott technológiai paraméterek felületi minőségre gyakorolt hatását. A munkadarabban lévő, a vasalási folyamatot megelőző, illetve követő maradó feszültségek, szintén vizsgálat tárgyát képezték. Az eredmények szerint a felület nyomó maradó feszültsége, amely az alkatrész müködési idejének meghosszabbítása miatt előnyös, a vasalási folyamatból következik. Azt tapasztalták, hogy a vasalási járatszám egy további fontos paraméter a megmunkált alkatrész hengeressége és keménysége szempontjából.

Az egyes vasalási paraméterek számszerü meghatározásánál (1. táblázat) figyelembe vettem a témában végzett irodalomkutatás, valamint az előzetes munkáim során tapasztaltakat, majd a múveleteket a Gyártástudományi Intézet mühelyébe telepített OPTIMUM (OPTIturn S600) típusú síkágyas CNC esztergagépen végeztem el $3,5 \mathrm{~mm}$ sugarú mesterséges gyémántot tartalmazó szerszámmal, szánkenő olaj kis mennyiségü kézi adagolása mellett.

1. táblázat. Vasalási paraméterek

\begin{tabular}{|c|c|c|}
\hline Technológiai paraméter & Érték & Mértékegység \\
\hline Vasalási járatszám (i) & 3 & - \\
\hline Vasalóerö (F) & 50 & $\mathrm{~N}$ \\
\hline Előtolás $(\mathrm{f})$ & 0,1 & $\mathrm{~mm} /$ ford \\
\hline Sebesség $\left(\mathrm{v}_{\mathrm{c}}\right)$ & 115 & $\mathrm{~m} / \mathrm{min}$ \\
\hline
\end{tabular}

\subsection{A hengeresség mérése}

A hengerelt darab alakhelyességének mérése Taylor Hobson gyártmányú Talyrond365 típusú köralakés helyzethiba-vizsgáló berendezésen történt, melynek alapfunkciói közé tartozik a tengelyre merőleges metszetbeli hibák feltárásakor a forgó munkadarabon a kívánt függőleges helyzetben rögzített mérőelemmel történő profilletapogatás. Ez a funkció alkalmas (többek között) a köralak és hengerességi hiba feltárására, kiértékelésére, ez utóbbit úgy értékeli, hogy kombinál egy bizonyos számú körkörösségi mérést, melyeket a vizsgálandó darab különbözö magasságaiban mért [8].

Az induktív szenzor segítségével a munkadarabot $2 \mathrm{~mm}$-es méréstartománnyal mértük $130 \mathrm{~mm}$ hosszon, a vizsgálandó hengeres felület homlokfelületeitöl 5-5 $\mathrm{mm}$ távolságra mind a felületvasalás elött és után.

A berendezés által vizsgált (az ISO 12180-1 szabványban meghatározott) hengerességi paraméterek közé tartozik az úgynevezett CYLp és CYLv értékek, melyek a referenciahengerhez viszonyítva ábrázolják az anyag legnagyobb eltérését kiemelkedések (peak) és bemélyedések (valley) formájában. A jelen vizsgálat során elsődlegesen figyelembe vett CYLt változása pedig ezen eltérések összegét adja meg (2. ábra), emiatt történt ennek az egy paraméternek a hangsúlyozása. 


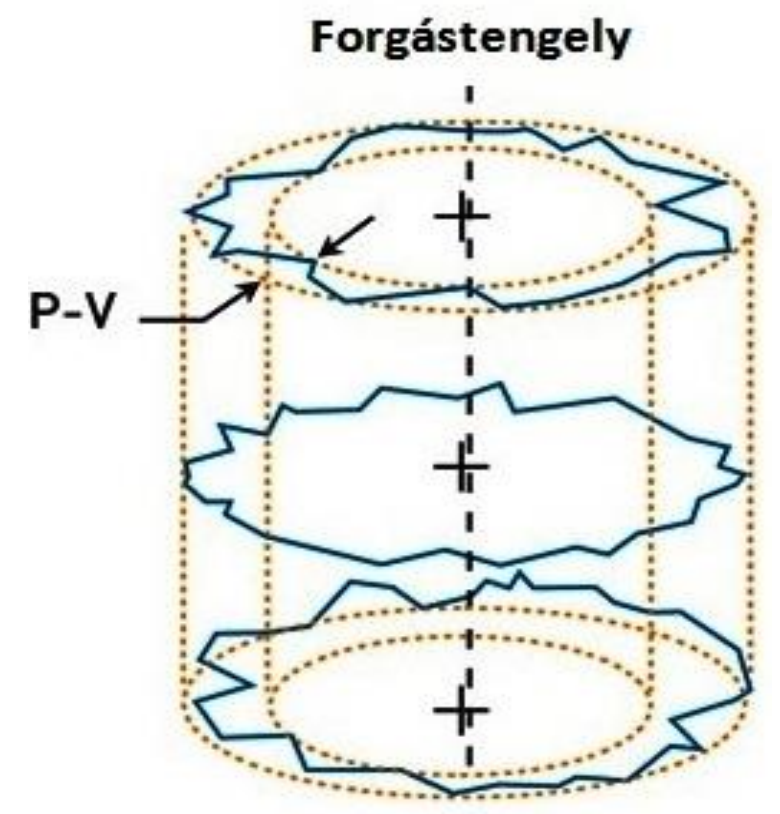

2. ábra CYLt hengerességi paraméter illusztrációja. [8]

\subsection{A felületi mikro-keménység mérése}

A próbadarabok felületi rétegének keménységmérése (vasalás előtt és után) a Miskolci Egyetem Müszaki Anyagtudományi Karának Fémtani, Képlékenyalakítási és Nanotechnológiai Intézetében lévő Instron gyártmányú Wilson Instruments Tukon 2100B típusú berendezésen történt.

Vickers keménység meghatározása történt, melynek elve, mint általában minden keménységmérés esetén, annak vizsgálata, hogy egy standard erőforrást alkalmazva, hogyan áll ellen a kérdéses anyag a képlékeny deformációnak. A mérés során egy $136^{\circ}$-os gyémántgúla nyomódik meghatározott erővel adott ideig (kísérletem esetében 0,1 N 10 másodpercen keresztül) a mérendő felületre. A kiértékelés során CCD kamera segítségével mértem meg a lenyomat átlóit és a kettő átlagából a berendezés saját szoftvere kiszámította a lenyomat felületét.

A minél pontosabb értékek rögzítése érdekében ellenőrző méréseket végeztem mind a munkadarab felületén, mind egy ellenőrzőtömbön, kalibrálva ezzel a készüléket, majd 9 ponton valósítottam meg mérést, melyekből a legalacsonyabb és legmagasabb értékeket kizártam.

\section{Eredmények}

A felületvasalás megvalósítása előtt és után is elvégeztem a króm-molibdén ötvözetü próbadarab hengerességének, majd felületi mikro-keménységének mérését, ez előbbire vonatkozó számszerü értékeket ismerteti a 3. ábra, melyet a mérőberendezés saját szoftvere generált. 


\begin{tabular}{|c|c|c|}
\hline \multicolumn{3}{|c|}{ Specification } \\
\hline Reference Type & & LS Cylinder \\
\hline Filter Type & & Gaussian \\
\hline \multicolumn{3}{|l|}{ 1-500upr } \\
\hline Datum & & Self \\
\hline Number Of Planes & 65 & \\
\hline \multicolumn{3}{|c|}{ Parameters } \\
\hline CYLP & 35.47 & $\mu \mathrm{m}$ \\
\hline CYLP Pos & 107.4 & \\
\hline CYLp PIn Zht & 206.24 & $\mathrm{~mm}$ \\
\hline CYLV & 5.62 & $\mu \mathrm{m}$ \\
\hline CYLV Pos & 45.2 & 0 \\
\hline CYLv PIn Zht & 176.24 & $\mathrm{~mm}$ \\
\hline CYLt & 41.09 & $\mu \mathrm{m}$ \\
\hline CYLtt & -7.38 & $\mu \mathrm{m}$ \\
\hline CYLtt Pos & 123.1 & - \\
\hline Profile Incl & 100.0 & $\%$ \\
\hline Total Runout & 41.09 & $\mu \mathrm{m}$ \\
\hline Coax ISO & 0.00 & $\mu \mathrm{m}$ \\
\hline Coax DIN & 3.53 & $\mu \mathrm{m}$ \\
\hline Conc & 0.00 & $\mu \mathrm{m}$ \\
\hline Height for Conc & 0 & $\mathrm{~mm}$ \\
\hline Avg Radius & 82.628 & $\mathrm{~mm}$ \\
\hline Cone Ang & -0.0020 & \\
\hline Angle & 90.000 & - \\
\hline Phase & 273.1 & - \\
\hline
\end{tabular}

a)

\begin{tabular}{|c|c|c|}
\hline \multirow{2}{*}{ Reference Type } & \multicolumn{2}{|l|}{ Specification } \\
\hline & & $\frac{\text { LS Cyinere }}{\text { Gaussian }}$ \\
\hline 1-500upr & & \\
\hline \begin{tabular}{|l|} 
Datum \\
\end{tabular} & & Self \\
\hline Number Of Planes & 65 & \\
\hline & Parameters & \\
\hline CYLP & 21.20 & $\mu \mathrm{m}$ \\
\hline CYLp Pos & 318.0 & \\
\hline CYLp PIn Zht & 186.24 & $\mathrm{~mm}$ \\
\hline CYLV & 5.07 & $\mu \mathrm{m}$ \\
\hline \begin{tabular}{|l|} 
CYLV Pos \\
\end{tabular} & 97.4 & \\
\hline CYLV PIn Zht & 204.24 & $\mathrm{~mm}$ \\
\hline CYLt & 26.27 & $\mu \mathrm{m}$ \\
\hline CYLIt & -4.71 & $\mu \mathrm{m}$ \\
\hline CYLtt Pos & 2.7 & \\
\hline \begin{tabular}{|l} 
Profile Incl \\
\end{tabular} & 100.0 & $\%$ \\
\hline Total Runout & 26.27 & $\mu \mathrm{m}$ \\
\hline Coax ISO & 0.00 & $\mu \mathrm{m}$ \\
\hline Coax DIN & 3.01 & $\mu \mathrm{m}$ \\
\hline Conc & 0.00 & $\mu \mathrm{m}$ \\
\hline Height for Conc & 0 & $\mathrm{~mm}$ \\
\hline \begin{tabular}{|l} 
Avg Radius \\
\end{tabular} & 82.628 & $\mathrm{~mm}$ \\
\hline Cone Ang & -0.0006 & \\
\hline Angle & 90.000 & \\
\hline Phase & 151.3 & \\
\hline
\end{tabular}

b)

3. ábra $A$ berendezés által számszerüsitett értékek a köszörült (a) és vasalt (b) felület esetén.

A hengeresség teljes jellemzéséhez szükséges a szerszámbefogó készülék adott síkjaiban mért értékek 3D-s ábrázolása is (4. ábra). Az induktív szenzorral végzett mérés jól mutatja a jellegzetes megmunkálási nyomokat, valamint a kúposság mértékének csökkenését.

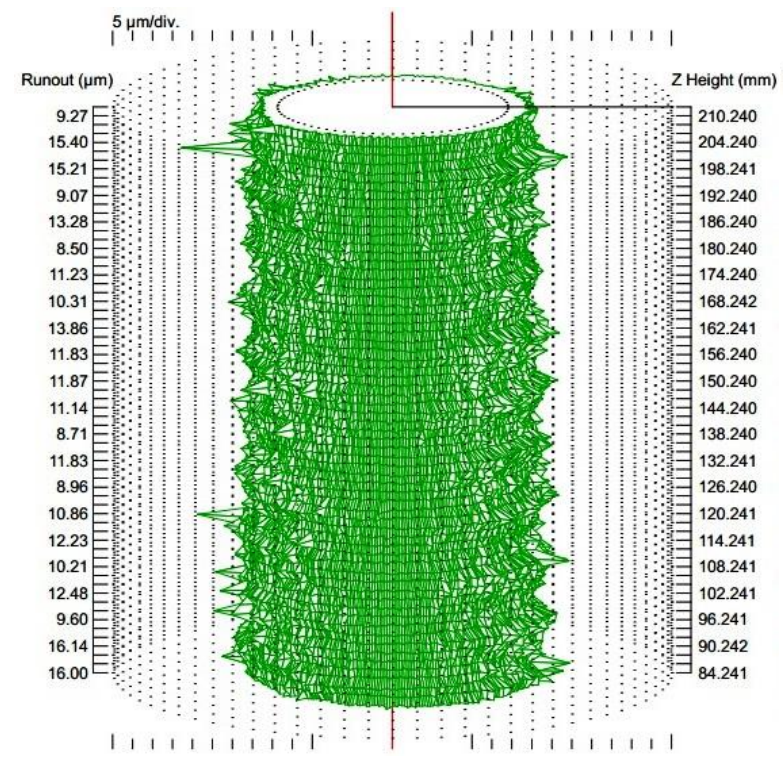

a)

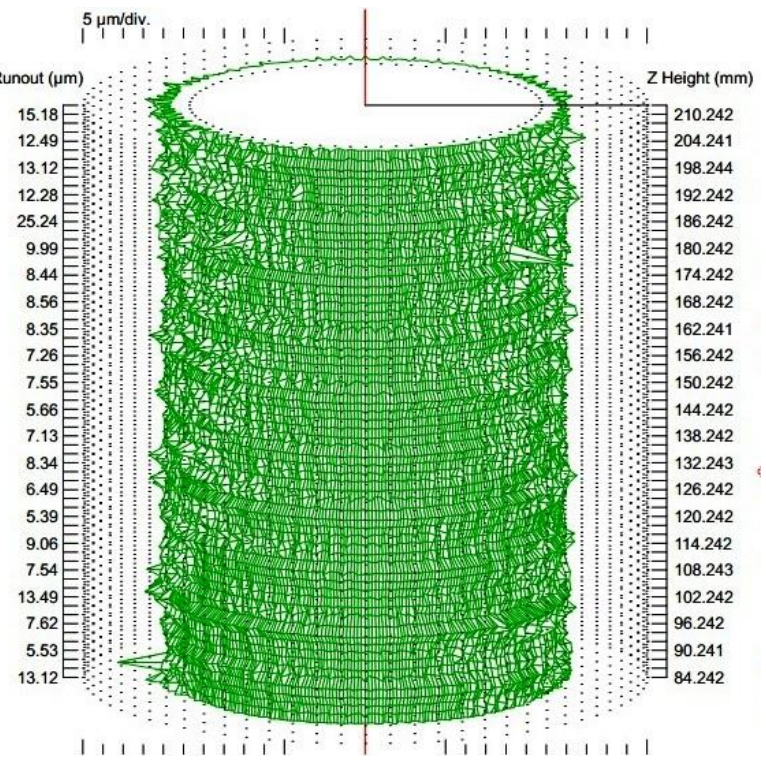

b)

4. ábra $A$ hengerességi eltérések 3D-s képei a köszörült (a) és vasalt (b) felület esetén. 
A felületi mikro-keménység mérésének eredményeit pedig az alábbi, 2. táblázat mutatja be, melyek a köszörült, illetve vasalt felület különböző pontjain vett mérések alapján került összefoglalásra.

2. táblázat. Mért felületi mikro-keménység

\begin{tabular}{|c|c|c|c|c|c|c|c|c|}
\hline \multicolumn{8}{|c|}{ Vickers keménység } & Átlag \\
\hline Köszörült & 320 & 313 & 336 & 352 & 433 & 313 & 320 & 341 \\
\hline Vasalt & 695 & 590 & 508 & 506 & 696 & 664 & 648 & 615 \\
\hline
\end{tabular}

\section{5. Összefoglalás}

A cikk egy hengerelt króm-molibdén ötvözetü tengelyszerü alkatrész felületvasalás okozta alakhelyesség- és felületközeli keménységváltozásának vizsgálatával foglalkozik. A kísérlet célja az volt, hogy megállapítsam a gyémántszerszámos vasalási eljárás kiemelt pozitív hatásai ennél az anyagminőségnél is érvényesülnek-e. A megmunkálási eljárás, valamint a mérési folyamatok megvalósításához modern, számítógéppel vezérelt és egyéni programmal ellátott berendezéseket alkalmaztam, ezzel is biztosítva a minél inkább relevánsabb eredményeket. A hengeresség javulását 3D-s ábrák formájában is ismertettem, a számszerü eredmények pedig azt mutatják, hogy több mint $60 \%$-kal (3. ábra) javult a darab alakhelyessége, vagyis CYLt értéke és a felületközeli réteg felkeményedésének mértéke pedig meghaladja a $180 \%$-ot.

Mindezek alapján egyértelmüen megállapítható, hogy a hideg képlékenyalakító vasalási eljárás előnyösen alkalmazható $42 \mathrm{CrMo} 4$ anyaminőségü külső hengeres felület esetén.

\section{Köszönetnyilvánítás}

„Az NKFI-125117 számú projekt a Nemzeti Kutatási Fejlesztési és Innovációs Alapból biztosított támogatással, a K_17 pályázati program finanszírozásában valósult meg."”

„A cikkben ismertetett kutató munka az EFOP-3.6.1-16-2016-00011 jelű „Fiatalodó és Megújuló Egyetem - Innovatív Tudásváros - a Miskolci Egyetem intelligens szakosodást szolgáló intézményi fejlesztése" projekt részeként - a Széchenyi 2020 keretében - az Európai Unió támogatásával, az Európai Szociális Alap társfinanszírozásával valósul meg".

\section{Irodalom}

[1] Bálint, L., Gribovszki, L.: A gépgyártástechnológia alapjai, Miskolci Egyetem (1975), pp.: 418442

[2] Scribner, I.A.: Burnishing tool, United States Patient Office, San Diego, California (1916), pp.:1-2

[3] Varga, Gy.: Can diamond burnishing be done in an environmentally friendly way? Applied Mechanics and Materials 2014, 474:411-416. https://doi.org/10.4028/www.scientific.net/AMM.474.411

[4] Luo, H., Liu, J., Wang, L., Zhong, Q.: The effect of burnishing parameters on burnishing force and surface microhardness, The International Journal of Advanced Manufacturing Technology 2006, 26(7-8):707-713. https://doi.org/10.1007/s00170-004-2412-0

[5] Akkurt, A.: Comparison of roller burnishing and other methods of finishing treatment of the 
surface of openings in parts from tool steel D3 for cold forming, Metal Science and Heat Treatment 2011, 53(3-4):145-150. https://doi.org/10.1007/s11041-011-9358-2

[6] Sequera, A., Fu, C.H., Guo, Y.G., Wei, X.T.: Surface Integrity of Inconel 718 by Ball Burnishing, Journal of Materials Engineering and Performance 2014, 23(9):3347-3353. https://doi.org/10.1007/s11665-014-1093-6

[7] Low, K.O., Wong, K.J.: Tribological effects of polimer surface modofications through plastic deformation, Bulletin of Materials Science 2011, 34(7):1549-1555. https://doi.org/10.1007/s12034-011-0357-0

[8] Varga, Gy., Hepp, I.: A Talyrond 365 típusú köralak- és helyzethiba vizsgáló berendezés használatának kezdő lépései, Oktatási segédlet, Miskolc, (2013) pp.: 5-6 